\title{
Extraosseous calcifying odontogenic cyst: a case report and a literature review
}

\author{
Cisto odontogênico calcificante: relato de caso e revisão da literatura
}

Claudia Cazal'; Ana Paula Veras Sobral'² Vânia Cavalcanti Ribeiro da Silva³; Vera Cavalcanti de Araújo ${ }^{4}$

\section{key word abstract}

Gorlin cysts

Calcificant odontogenic cyst

The calcifying odontogenic cyst is an uncommon odontogenic lesion that can have intra- or extraosseous occurrence with both cystic or tumor behavior. A report of an extraosseous calcifying odontogenic cyst (ECOC) in a 57-year-old black woman is presented as well as a review of the literature about the Odontogenic tumours lesion. The clinical, radiographic and histopathologic features are discussed, along with etiology and treatment.

resumo

O cisto odontogênico calcificante é uma lesão odontogênica incomum que pode ser intra ou extra-óssea, tanto com um comportamento cístico quanto com um comportamento neoplásico. Neste trabalho está sendo apresentado o relato de um caso de cisto odontogênico calcificante em uma mulher da raça negra, com 57 anos de idade, bem como uma revisão da literatura sobre a lesão. Os achados clínicos, radiográficos e histopatológicos são discutidos, assim como sua etiologia e o seu tratamento. Ulltima submissão em 11/08/05 Aceito para publicação em 20/9/05 Publicado em 20/12/05

\section{Introduction}

The calcifying odontogenic cyst (COC) is a rare odontogenic lesion first described as a distinct entity by Gorlin et al., in $1962^{(8)}$. Since then, literature shows a large controversy regarding terminology and classification in spite of the currently acceptation of Gorlin's original designation by the World Health Organization (WHO) in $1971^{(17)}$.

Subsequently, WHO(11), who first recognized and defined the $\mathrm{COC}$ as a non-neoplastic cystic lesion ${ }^{(17)}$, classified the entity and its variants as an odontogenic tumor rather than an odontogenic cyst.

The neoplastic lesions were subdivided in three subgroups based on location (intraosseous and extraosseous) and histological features. Despite its variable clinical characteristics, COC is often referred as an asymptomatic slow growing swelling of the jaws or gingival tissues, depending upon whether the lesion is intra- or extraosseous. The extraosseous COC is less common, comprising $12 \%$ to $20 \%$ of the

1. MDS; Oral Pathology Department - School of Dentistry; doctorate student at Universidade de São Paulo.

2. PhD; professor at the Oral Pathology Department of the School of Dentistry, Universidade de Pernambuco.

3. Professor at the Oral Diagnosis Department of the School of Dentistry, Universidade de Pernambuco.

4. PhD; professor and chairman of the Department of Oral Pathology, Faculdade de Odontologia São Leopoldo Mandic. 
reported cases $^{(2,12)}$. Clinically it appears as a localized or pedunculated gingival mass with no distinctive features ${ }^{(2,12)}$, and radiographically it shows no or only superficial bone involvement with surface erosion ${ }^{(21)}$.

The histological features of peripheral COC are similar to the intraosseous COC characteristics, and include an epithelial lining of varied thickness, composed of a distinct columnar (and occasionally cuboidal) basal layer, with cells that contain darkly staining nuclei, polarized away from the basement membrane and palisading, similar to the ameloblasts. Within the epithelial lining there is an irregular collection of cells, including sheets of stellate reticulum and eosinophilic cells so called ghost cells. Next to the basal layer, irregular or dysplastic dentin and osteoid can also be found ${ }^{(17)}$.

By the year 1991 only 54 cases of extraosseous calcifying odontogenic cysts had been reported. Forty-five cases of COC were discussed by Buchner et al., in 1991(3), this including seven new cases of extraosseous COC. Eleven years after that, a MEDLINE (1993-2005) research was performed and exhibited only 13 new cases of peripheral COC published in the English literature (Table 1).

Treatment involves enucleation of the lesion and long-term follow-up ${ }^{(2,19)}$. Recurrences are uncommon and probably related to incomplete cyst removal(19).

The present paper reports a documented case of an uncommon extraosseous calcifying odontogenic cyst (ECOC) with a review of the literature.

\section{Case report}

A 57-year-old black woman was referred to the Oral Diagnosis Department of Universidade de Pernambuco, for evaluation and treatment of an asymptomatic swelling in the retromolar region with a three-month evolution.
Clinically a well-defined mass on the hind right side of the mandible, with $0.5 \mathrm{~cm}$ of diameter, firm consistency and a reddish overlying mucosa was observed. The orthopantomograph showed no osseous involvement, but a well-circumscribed extraosseous image with an osteogenic reaction of the subjacent bone. Amounts of calcified material scattered throughout the lesion were visible (Figure 1). Clinical diagnosis suggested ossifying fibroma, Gorlin cyst or a residual inflammatory cyst.

Excisional biopsy was performed and the surgical specimen was submitted to histopathologic evaluation at the Oral Pathology Department of the same center. The lesion was paraffin embedded and stained with hematoxylin and eosin (H\&E), and after that, evaluated with optical microscopy.

Microscopically, sections showed a hemisected soft tissue specimen superficially composed of a stratified squamous epithelium lining and a subjacent fibrous connective tissue. Within this connective tissue odontogenic epithelium islands resembling ameloblastoma features could be observed

(Figure 2). Those neoplastic islands exhibited basal cells with a cuboidal or columnar aspect similar to ameloblasts (Figure 3). Sheets of loose myxomatous tissue were also observed and interpreted as stellate reticulum-like tissue

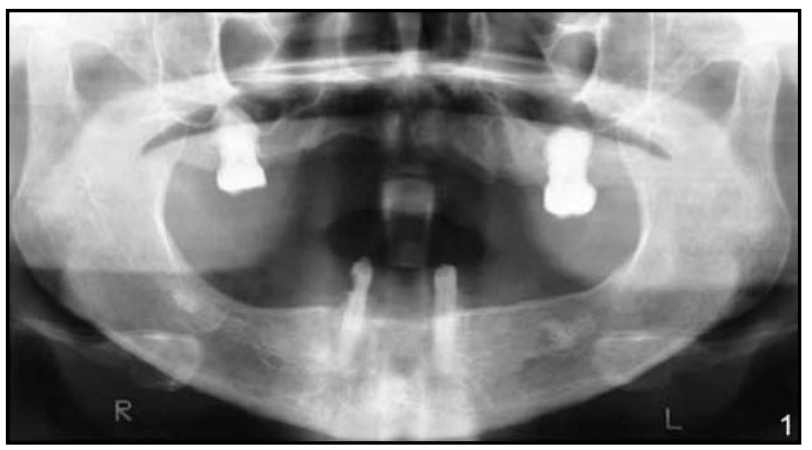

Figure 1 - Orthopantomograph showing an osteogenic reaction of the subjacent bone. A relationship with the bone is not present

Table 1 Cases of extraosseous calcifying odontogenic cyst reported in the literature until 2005

\begin{tabular}{lccccc}
\hline Authors & Year of publication & Number of cases & Age & Gender & Localization \\
Various $^{(3)}$ & $1962-1988$ & 38 & $9-89$ & $18 \mathrm{M}, 20 \mathrm{~F}$ & 19 mandible, 19 maxilla \\
${\text { Mascrès et al. }{ }^{(13)}}$ & 1990 & 1 & 56 & $1 \mathrm{M}$ & 1 mandible \\
Buchner et al. $^{(3)}$ & 1991 & 7 & $10-92$ & $3 \mathrm{M}, 4 \mathrm{~F}$ & 7 mandible \\
Hong et al. $^{(10)}$ & 1991 & 8 & $37-79$ & $4 \mathrm{M}, 4 \mathrm{~F}$ & 7 mandible, 1 nonspecified \\
Moleri et al. ${ }^{(14)}$ & 2002 & 1 & 66 & $1 \mathrm{~F}$ & 1 mandible \\
Orsini et al. ${ }^{(16)}$ & 2002 & 1 & 39 & $1 \mathrm{M}$ & 1 mandible \\
Fregnani et al..$^{(7)}$ & 2003 & 2 & $10-38$ & $2 \mathrm{~F}$ & 2 maxila \\
\hline
\end{tabular}


resembling the enamel organ and a variable number of ghost cells (Figure 4). Irregular foci of calcified material resembling dentin were visualized throughout the specimen.

Based on these features the proposed histopathologic diagnosis was extraosseous calcifying cyst or Gorlin cyst. Healing was uneventful, and the lesion had not recurred after a four-year follow-up.

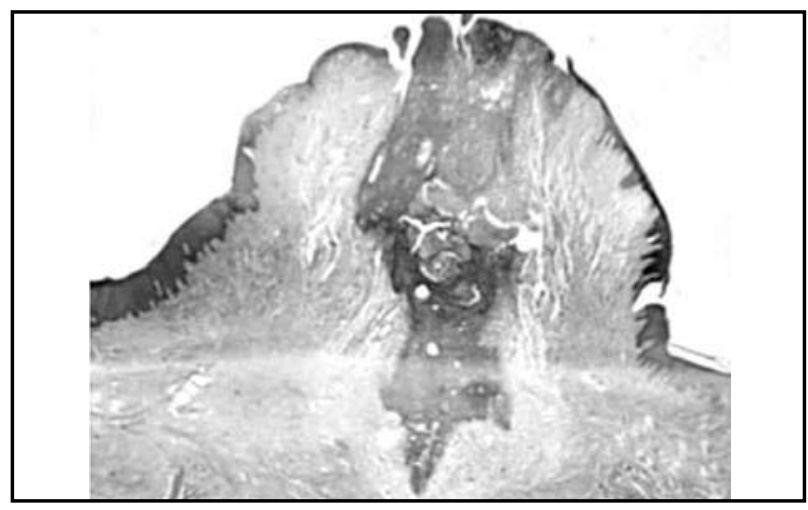

Figure 2 - Low-power photomicrograph in H\&E of the ECOC (x 100)



Figure 3 - Neoplasic cells high-power photomicrograph (H\&E) resembles the stellate reticulum of an ameloblastoma $(x 320)$

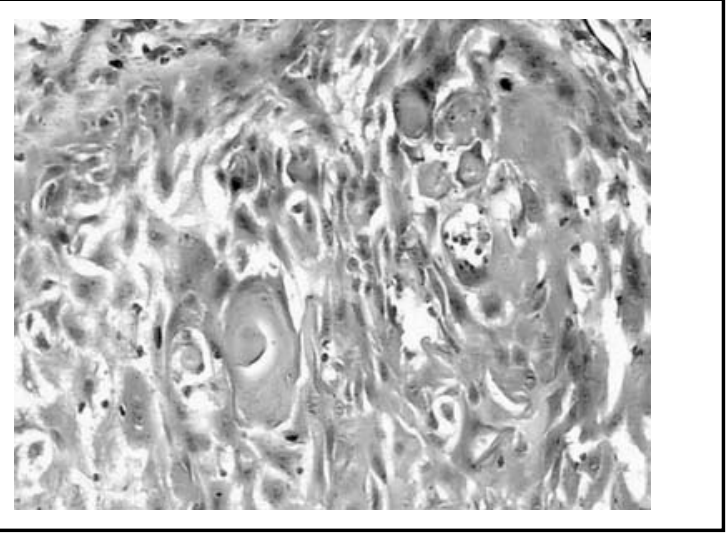

Figure 4 - Photomicrograph of the ghost cells and other neoplasic cells (H\&E, x 200)

\section{Discussion}

The COC is also known as Gorlin cyst since its initial description, in 1962, by that author ${ }^{(8)}$. It is considered a unique entity with both cystic and neoplastic behavior. Peripheral varieties are usually located on the gingiva and alveolar mucosa. They generally appear as circumscribed elevated masses, with smooth surface and firm or soft consistency. Since they have no characteristic clinical appearance they can resemble granulomas, fibrous hyperplasic or fibromas ${ }^{(12,18,19)}$.

The presented case, similar to other reports in the literature was an asymptomatic localized gingival swelling. Clinical presentations of the ECOC are often described as variable or non-specific ${ }^{(2,5)}$.

Our patient was a 57-year-old woman, but contradicting the literature, her lesion was located in the retromolar region. Review of the epidemiological characteristics of the ECOC has shown that the tumor has predilection neither for gender ${ }^{(6)}$ nor for age ${ }^{(13,15,20)}$. However, some authors have described two peaks of occurrence in the second and sixth decades ${ }^{(2,12)}$. Also, no overall predilection was shown for either maxilla or mandible ${ }^{(12)}$, although a tendency to occur in the anterior region is described ${ }^{(2)}$.

As an extraosseous lesion, $\mathrm{COC}$ exhibits no or minimal radiographic changes ${ }^{(12)}$. It may appear as a radiolucent area with scattered amounts of opacities and no relationship with the subjacent bone. We observed a slightly higher condensation on the subjacent bone that was probably caused by compressive pressure of the lesion.

Some attention concerning intraosseous lesions must be taken to exclude cases that perforated the cortex and exteriorized.

Although histological criteria have been established for the diagnosis of the $\operatorname{COC}^{(17)}$, its pathogenesis is still speculative. Freedman et al. ${ }^{(6)}$ proposed that the neoplastic cell is originated from a well-differentiated ameloblast, and its neural crest origin confers to this cell a pleuripotential capacity to undergo terminal differentiation. Starting from the postulate that ameloblasts are stem cells, terminal differentiation is not necessarily required to originate the $\mathrm{COC}$ neoplastic cell. This fact might justify the ameloblasticlike morphology observed in those neoplasms.

Praetorius et al. ${ }^{(18)}$ and Buchner et al. ${ }^{(3)}$ believe COC cystic epithelium is originated from the reduced enamel organ, from islands of odontogenic epithelium within the tooth follicle or from the remnants of odontogenic epithelium in the bone or gingival tissue. In the reported 
case, we believe the neoplastic epithelium arised from the odontogenic remnants of the overlying mucosa due to the lesion intimacy with the oral surface and absence of tooth or bone involvement. But whether the cyst develops as central or peripheral lesion probably depends on the location of the odontogenic epithelium, which constitutes the source of the lesion. Nevertheless, the location does not seem to have any relation to either behavior or histological features of the cyst ${ }^{(3,18)}$.
According to some reports ${ }^{(11,19)}$, neoplastic or solid lesions constitute $2 \%$ to $10 \%$ of all cases, and are more often associated with peripheral location.

Treatment of the extraosseous COC involves surgical excision $^{(3-6,12,20)}$ and recurrences are unexpected $(1,4,20)$. Generally, cystic COC have good prognosis, but the neoplastic cases are uncertain. When a COC is associated with other odontogenic tumors, treatment and prognosis must be based on the associated lesion ${ }^{(9,15,21)}$.

\section{References}

I.ALTINI, M.; FARMAN,A. G. The calcifying odontogenic cyst: eight new cases and a review of the literature. Oral Surg, v. 40, p. 75I, 1975.

2. BUCHNER, A. The central (intraosseous) calcifying odontogenic cyst: an analysis of 215 cases. J Oral Maxillofac Surg, v. 49, n. 4, p. 330-9, 1991.

3. BUCHNER,A et al. Peripheral extraosseous calcifying odontogenic cyst. A review of forty-five cases. Oral Surg Oral Med Oral Pathol, v. 72, n. I, p. 65-70, 1991.

4. CURI, M. M.; DIB, L. L.; SOUZA, R. S. Central epithelial odontogenic ghost cell tumor: a case report. RPG, v. 7, n. I, p. 90-4, 2000.

5. EL-BEIALY, R. R.; EL-MOFTY, S.; REFAL, H. Calcifying odontogenic cyst: case report and review of the literature.J Oral Maxillofac Surg, v. 48, n. 6, p. 637-40, 1990.

6. FREEDMAN, P. D.; LUMERMAN, H.; GEE, J. K. Calcifying odontogenic cyst: a review and analysis of seventy cases. Oral Surg Oral Med Oral Pathol, v. 40, p. 93-106, 1975.

7.FREGNANI, E. R. et al. Calcifying odontogenic cyst: clinicopathological features and immunohistochemical profile of 10 cases.J Oral Pathol Med, v. 32, p. 163-70, 2003

8. GORLIN, R. J. et al. The calcifying odontogenic cyst: a possible analogue of the cutaneous calcifying epithelioma of Malherbe. Oral Surg Oral Med Oral Pathol, v. I 5, p. 1235-43, 1962.

9. HIRSHBERG,A.; KAPLAN, l.; BUCHNER,A. Calcifying odontogenic cyst associated with odontoma. J Oral Maxillofac Surg, v. 52, p. 555-8, 1994.

I0. HONG, S. P.; ELLIS, G. L;;HARTMAN, K. S. Calcifying odontogenic cyst.A review of ninety-two cases with reevaluation of their nature as cysts or neoplasms, the nature of ghost cells, and subclassification. Oral Surg Oral Med Oral Pathol, v. 72, p. 56-64, 1991.
I I. KARAMER, I. R. H.; PINDBORG, J..):; SHEAR, M. WHO Histological Typing of Odontogenic Tumour. $2^{\text {nd }}$ ed. Geneva: SpringerVerlag, 1992.

12. KAUGARS, C. C.; KAUGARS, G. E.; DE BIASI, G. F. Extraosseous calcifying odontogenic cyst: report of case and review of literature. JADA, v. I19, p. 7। |-8, 1989.

13. MASCRÈS, C.; DONOHUE,W. B.; VAUCLAIR, R. The calcifying odontogenic cyst: report of a case.J Oral Maxillofac Surg, v. 48, p. 319-22, 1990.

14. MOLERI, A. B.; MOREIRA, L. C.; CARVALHO, J. J. Comparative morphology of 7 new cases of calcifying odontogenic cysts. J Oral Maxillofac Surg, v. 60, p. 689-96, 2002.

15. NEVILLE, B. W. et al. Oral and Maxillofacial Pathology. $2^{\text {nd }}$ ed. Philadelphia: Saunders, 2002.

16. ORSINI, G. et al. Peripheral calcifying odontogenic cyst. J Clin Periodontol, v. 29, n. I, p. 83-6, 2002.

17.PINDBORG, J. J.; KRAMER, I. R. H.;TORLINI, H. Histological typing of odontogenic tumours, jaw cysts, and allied lesions. Geneva: $\mathrm{WHO}, 1971$.

18. PRAETORIUS, F. et al. Calcifying odontogenic cyst. Acta Odontol Scand, v. 39, p. 227-40, 1981.

19. SIKES, J.W.; GHALI, G. E.;TROULIS, M. J. Expansile intraosseous lesion of the maxilla. J Oral Maxillofac Surg, v. 58, p. I395400, 2000.

20. STEINBERG, M. J.; HERRERA, A. F.; FRONTERA, Y. Mixed radiographic lesion into the anterior maxilla in a 6-year-old boy.J Oral Maxillofac Surg, v. 59, p. 317-21, 200 I.

21. SWAN, R. H.; HOUSTON, G. D.; MOORE, S. P. Peripheral calcifying odontogenic cyst (Gorlin cyst). J Periodontol, v. 56, n. 6, p. 340-3, 1985. 